УДК 336.1:352

DOI: https://doi.org/10.37320/2415-3583/11.36

Ливдар М.В.

кандидат економічних наук, доцент, доцент кафедри фінансів, Національний університет «Львівська політехніка» ORCID: https://orcid.org/0000-0003-1925-7781

Федевич Л.С. кандидат економічних наук, доцент, доцент кафедри фінансів, Начіональний університет «Львівська політехніка» ORCID: https://orcid.org/0000-0002-3097-7467

Корначук О.Ю. студентка,

Національний університет «Львівська політехніка»

\title{
ДОСВІД ПРОЦЕСУ ДЕЦЕНТРАЛІЗАЦІЇ У КРАЇНАХ ЄВРОПИ
}

Децентралізація була і залишається провідним способом реформування економічних систем країн світу, щзо дає змогу кониентрувати більше коштів у органах місиевого самоврядування. У прочесі проведення реформ місиеві органи управління отримують більше прав та можливостей, особливо у розпорядженні фінансовими ресурсами, для забезпечення якісного обслуговування та модернізачії своїх адміністративно-територіальних одиниць із метою покращення життя громадян. Розглянуто досвід зарубіжних країн, який показуе способи акумулювання коштів у місиевих бюджетах та покращення якості життя громадян, а також рівномірного навантаження регіонів відповідно до їхніх можливостей. Досліджено особливості та механізми децентралізації в країнах Європи, зокрема, досвід Італії, Польщі, Румунії та Латвії. Виділено основні напрями проведення реформ із децентралізації в Україні.

Ключові слова: децентралізація, бюджет, місцеве самоврядування, регіон.

Постановка проблеми. В умовах сучасного світу, де відбувається постійний процес розвитку країн та удосконалення наявних у них управлінських систем, все частіше постає питання розвитку громадянського суспільства за рахунок місцевих органів та інституцій. Провідні країни Європи знайшли вирішення цієї проблеми у проведенні реформ, які полягають у реструктуризації наявної системи управління та наданні більших повноважень та свободи місцевим органам самоврядування. Такий процес і являє собою децентралізаційні реформи. Саме ці реформи забезпечують рушійні зміни та розвиток країн, адже місцеві органи краще орієнтуються у потребах та можливостях свого регіону і можуть ефективніше використовувати наявні ресурси для вирішення нагальних та перспективних завдань.

Варто зауважити, що процес децентралізації Європи був досить своєрідним у різних країнах відповідно до умов присутнього в них розвитку суспільства. Саме досвід країн Свропи потрібно дослідити, щоб з'ясувати досягнення реформ та труднощі, з якими ці держави зіткнулися.

Аналіз останніх досліджень та публікацій. Процес та механізм децентралізації в різних країнах у вітчизняній та світовій літературі вивчали та аналізували такі фахівці, як: В. Борденюк, який приділяв увагу децентралізації влади та місцевого управління; О. Бориславська та I. Заверуха, які у спільній праці висвітлили досвід європейських країн та перспективи для України [1]; М. Іжа, який дослідив показники децентралізації в країнах Європи [2]. Також Д.Є. Хріпливець досліджував моделі місцевого самоврядування [3]. Що стосується зарубіжних праць, то Я. Брюкнер працював над темою фіскальної децентралізації в країнах, що розвиваються, зокрема над впливом корупції та податкової системи тощо.

Мета статті. Метою написання цієї статті $\epsilon$ дослідження особливостей та механізмів децентралізації в країнах Європи та висвітлення їхніх головних досягнень та проблем у реформаційних процесах. Це дослідження спрямоване на виділення головних аспектів розподілу повноважень у європейських країнах для того, щоб взяти їх за приклад для України.

Виклад основного матеріалу. Децентралізація - це перерозподіл повноважень, зобов'язань та фінансових ресурсів від державних органів влади до місцевих органів самоврядування, тобто якнайближче до громадянського суспільства.

Процеси децентралізації в країнах Свропи $\epsilon$ хорошим прикладом того, як вони можуть впливати на зміни у системі взаємозв'язків влади та врегулювання відносин у суспільстві. Варто відзначити те, що для країн із перехідним типом економіки децентралізація являє собою рушійний чинник змін суттєвих сегментів як країни, так $\mathrm{i}$ конкретно місцевого розвитку [4].

Для дослідження децентралізаційних реформ у європейських країнах варто розглянути досвід їх проведення в Італії, Польщі, Румунії та Латвії. 
Наслідком реформ влади в Італії стало формування системи влади на трьох рівнях: регіон провінція - комуна. В Італії було прийнято закон про фінансування місцевого самоврядування, який був спрямований на концентрацію частини національних податкових надходжень у міського управління, щоб відшкодувати скасовані в результаті реформ державні трансферти [5].

Але процес децентралізації в Італії має досить вагомі недоліки. У запровадженому трирівневому поділі держави повноваження кожної ланки дуже часто збігаються. Це спричинено тим, що законодавчі органи Італії не встановили чітких переліків та меж у діяльності регіонів, провінцій та комун під час вирішення конкретних завдань, що досить часто приводить до конфліктних ситуацій. Навіть у процесі перерозподілу фінансових ресурсів серед органів міського самоврядування через недосконалість законодавчої бази реформ найменші адміністративні одиниці страждають. Це стосується, зокрема, комун. Саме комуни часто недоотримують фінанси для нормального функціонування та виконання зобов'язань. Механізм розподілу податків та податкової рівності в Італії на рівні регіону та міст є досить недосконалим, $\mathrm{i}$, як наслідок, виникає нечесне фінансування різних ланок країни [6].
У регіональних бюджетах концентруються видатки на забезпечення освіти, охорони здоров'я, транспортних мереж, цивільної авіації, надання адміністративних послуг для промисловості та бізнесу. До повноважень регіонів в Італії належать також питання територіального планування та розвитку, які наведені у таблиці 1.

Як бачимо $з$ таблиці, найбільш відповідальні повноваження має регіон, відповідно, він найкраще фінансується, через що і виникають фінансові труднощі у менших ланках.

Що стосується Польщі, то там необхідність децентралізації загострилась у зв'язку 3 масовими процесами лібералізації та здійснення ринкових реформ. Головною метою іï проведення стало забезпечення самостійного функціонування кожного регіону, створення нових і відкритих політичних інститутів і збільшення впливу громадянських інститутів. Початком реформи було створення гмін - територіальних громад. Крім того, більшими ланками є повіт та сеймік. Через це у Польщі змінився розподіл повноважень між центральними і місцевими органами влади. Наступним кроком у процесі реформи було зменшення кількості державних службовців, що мало хороший вплив на скорочення бюджетних витрат на управління. Також був змінений механізм пере-

Таблиця 1 - Трирівнева система управління в Італії

\begin{tabular}{|c|c|c|c|}
\hline Рівень & Характеристика & \begin{tabular}{|l|} 
Кількість \\
\end{tabular} & Сфери компетенції \\
\hline Регіон & $\begin{array}{l}\text { Найбільша одиниця місцевого } \\
\text { самоврядування країни. У } \\
\text { межах своїх можливостей та } \\
\text { повноважень регіони мають } \\
\text { право брати участь у програмах } \\
\text { та проектах ЄС. }\end{array}$ & 20 & $\begin{array}{l}\text { 1. Освіта. } \\
\text { 2. Охорона здоров’я. } \\
\text { 3. Транспорт та цивільна авіація. } \\
\text { 4. Планування територіальних одиниць та їх } \\
\text { розвиток. } \\
\text { 5. Надання адміністративних послуг для } \\
\text { промисловості та бізнесу. }\end{array}$ \\
\hline Провінція & $\begin{array}{l}\text { Середня ланка системи } \\
\text { управління. Рада провінцій } \\
\text { може складатися з 24-45 } \\
\text { членів, залежно від загальної } \\
\text { кількості їі населення. Окремим } \\
\text { завданням провінцій є підтримка } \\
\text { співробітництва та партнерства } \\
\text { між комунами. }\end{array}$ & 110 & $\begin{array}{l}\text { 1. Підтримка та модернізація громадського } \\
\text { транспорту, авториза-ція приватного транспорту та } \\
\text { ко-нтроль за ним. } \\
\text { 2. Ремонт доріг у межах провінцї та супутня } \\
\text { інфраструктура. } \\
\text { 3. Управління на території та екологічний захист, } \\
\text { включаючи вивіз відходів та їх переробку. } \\
\text { 4. Нагляд за функціонуванням середньої освіти. } \\
\text { 5. Створення центрів зайнятості, центрів надання } \\
\text { соціальних послуг. } \\
\text { 6. Розвиток культури, спорту та туризму. } \\
\end{array}$ \\
\hline Комуна & $\begin{array}{l}\text { Найменша ланка функціонування } \\
\text { системи. Вона } є \text { найближчою } \\
\text { до громадян. Рада комун } \\
\text { може складатися залежно від } \\
\text { населення з 12-60 учасників. } \\
\text { Мер виконує частину } \\
\text { делегованих функцій і веде облік } \\
\text { смертності, народжуваності } \\
\text { тощо, а також стежить за } \\
\text { громадським порядком. }\end{array}$ & 8000 & $\begin{array}{l}\text { 1. Встановлення та стягнення місцевих податків. } \\
\text { 2. Діяльність місцевої поліції. } \\
\text { 3. Охорона здоров’я та надання послух в соціальних } \\
\text { сферах на місцевому рівні. } \\
\text { 4. Нагляд за початковою та середньою освітою. } \\
\text { 5. Збір та знищення сміттєвих відходів. } \\
\text { 6. Місцева транспортна мережа та освітлення } \\
\text { вулиць. } \\
\text { 7. Надання дозволів на торгівлю. } \\
\text { 8. Надання соціального житла. }\end{array}$ \\
\hline
\end{tabular}

Джерело: складено авторами на основі [7] 


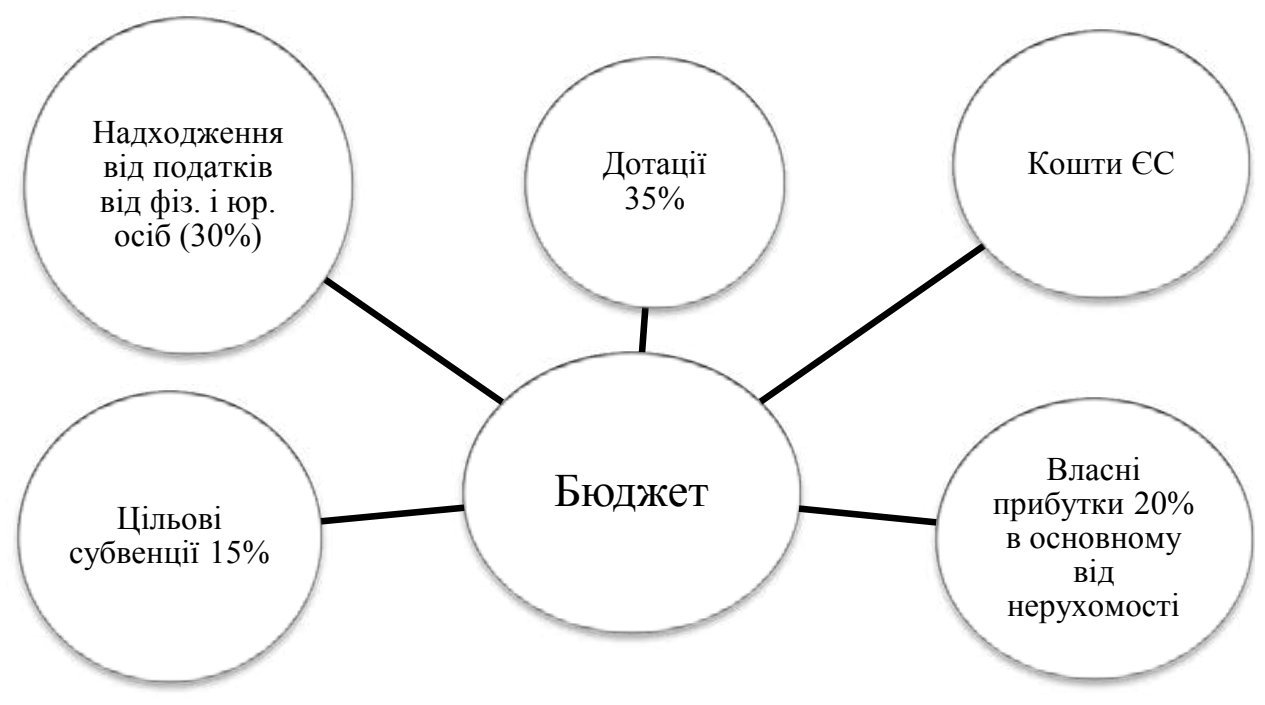

\section{Рисунок 1 - Механізм формування бюджету для виконання повноважень у Польщі}

Джерело: складено авторами на основі [4; 8]

розподілу податкових надходжень між бюджетами усіх рівнів [8].

Функції та компетенції кожного рівня управління є досить схожими, але незалежними, тому що вони відповідають виключно за свою тери- торію. До компетенцій кожної ланки на їхньому рівні входить: публічна освіта, охорона здоров'я, безпека громадян, освітлення вулиць, спорт, туризм, культура, соціальна допомога, обороноздатність, родинна політика тощо.

Таблиця 2 - Система управління в Румунії

\begin{tabular}{|c|c|c|c|}
\hline Рівень & $\begin{array}{c}\text { Місцеві } \\
\text { представницькі } \\
\text { органи влади } \\
\end{array}$ & $\begin{array}{c}\text { Місцеві виконавчі } \\
\text { органи влади }\end{array}$ & Компетенції \\
\hline Жудець & Рада Жудеця & Голова Ради Жудеця & $\begin{array}{l}\text { 1. Координація діяльності місцевих рад. } \\
\text { 2. Управління та контроль за державними послугами. } \\
\text { 3. Технічна та юридична допомога місцевим радам. } \\
\text { 4. Охорона екології. } \\
\text { 5. Затвердження бюджету жудеця. } \\
\text { 6. Розбудова міст. } \\
\text { 7. Технічне оснащення та модернізація доріг Жудеця. } \\
\text { 8. Формування податків для жудеця. } \\
\text { 8. }\end{array}$ \\
\hline Муніципій & $\begin{array}{l}\text { Рада Муніципію } \\
\text { (Міста) }\end{array}$ & Прімар & $\begin{array}{l}\text { 1. Адміністрування публічної та приватної власності } \\
\text { муніціпія/ міста. } \\
\text { 2. Безпека навколишнього середовища. } \\
\text { 3. Затвердження регламенту місцевої ради. } \\
\text { 4. Впровадження та затвердження місцевих податків. } \\
\text { 5. Управління місцевим бюджетом. } \\
\text { 6. Захист інвестиційних інтересів муніціпія/міста. } \\
\text { 7. Стратегія економічного та соціального розвитку } \\
\text { муніціпія/міста. } \\
\text { 8. Мостове будівництво та дороги міського значення. } \\
\text { 9. Надання соціального житла. }\end{array}$ \\
\hline Комуна & Рада Комуни & Прімар комуни & $\begin{array}{l}\text { 1. Водопостачання, каналізація, вивезення сміття. } \\
\text { 2. Облік населення та видача відповідних документів. } \\
\text { 3. Доставляння публічних послуг громадянам. } \\
\text { 4. Встановлення та затвердження місцевих податків, } \\
\text { відповідно до чинного законодавства. } \\
\text { 5. Охорона порядку. } \\
\text { 6. Захист пам’яток архітектури та історії. }\end{array}$ \\
\hline
\end{tabular}

\footnotetext{
* Складено авторами на основі [7; 8]
} 
Варто розглянути структуру наповнення та формування бюджету Польщі.

Надходження від податків фізичних та юридичних осіб становлять аж $30 \%$. Із тієї загальної частки з податку фізичних осіб $38 \%$ залишається в гмінах, $10 \%$ - у повітах, $1,5 \%$ йде в обласний бюджет. А 3 надходжень від податку на прибутки юридичних осіб: 5\% залишається в гмінах, $1-2 \%$ - у повітах, більше $10 \%$ йдуть в обласний бюджет. Незалежність гміни є досить високою, адже в Польщі їм дозволяється 85\% коштів свого бюджету використовувати на власний розсуд без узгодження 3 центральними органами влади. Близько $15 \%$ коштів бюджету міська влада заробляє самотужки. Варто відзначити, що частки податків та дотацій для кожного рівня вираховується автоматично на основі спеціальних формул, що порівняно з Італією не створює нерівностей та тягарів у фінансуванні окремих одиниць органів місцевого самоврядування [8].

У процесі проведення децентралізації Польщі появився чіткий поділ функцій та повноважень між державною та місцевою владою. Основними напрямами змін для польського уряду є: зовнішня політика, безпека та охорона національної цілісності, розроблення стратегічних напрямів розвитку держави. Місцева влада отримала повноваження щодо економічного та соціального розвитку регіонів, розподіл грошових фондів та майна територіальної громади, ведення відокремленого фінансового господарства. Заходи, здійснені польським урядом у процесі децентралізації, дали поштовх для зростання інвестицій у державі, розвитку малого бізнесу та суспільства загалом.

Процес децентралізації в Румунії був досить довгим i зберігав пріоритетне місце під час реструктуризації системи управління державою згідно з Програмою Уряду за 2005-2008 рр. Головним чинником початку такого процесу в Румунії, як і в більшості країн, є забезпечення співвідношення наданих повноважень та зобов'язань із потрібними ресурсами для ефективного їх використання 3 метою задоволення громадянських потреб. Розподіл фінансів у цій країні дав змогу концентрувати кошти в місцевих бюджетах, а також розподіляти і поповнювати їх на власний розсуд.

Відповідно до Законодавства Румунії, вона розділена на 8 регіонів, що розвиваються, але самі по собі не $\epsilon$ адміністративними одиницями, а лише слугують координаторами та посередниками регіонального розвитку. Регіони розвитку включають у себе 41 жудець та 1 муніципію (так також виділяється столиця Румунії - Бухарест). Жудеці поділені на 2686 комун та 256 інших муніципій [9]. Саме комуни і муніципії приймаються за найменші адміністративно-територіальні одиниці країни. Детальнішу характеристику окремих ланок системи наведено у таблиці 2.
Варто приділити особливу увагу досвіду децентралізації у країнах, що були у складі Радянського Союзу. Актуальність цього полягає у подібності умов у цих країнах з Україною. Тобто це може бути хорошим прикладом для України, щоб уникнути певних помилок.

Децентралізаційна реформа в Латвії була закінчена у 2009 році. Вона охопила три основні напрями в країні: юридичний, адміністративно-територіальний та фіскальний. Потрібно зробити наголос на тому, що кожен напрям здійснювався відокремлено, не узгоджувався з іншими. Метою проведення адміністративно-територіальної реформи було створення адміністративних територій iз місцевим та регіональним самоврядуванням, які здатні самостійно розвиватися і дадуть населенню можливість отримувати якісні послуги. Проте введення цієї реформи відбувалося із значними ускладненнями, що привело до збільшення терміну упровадження децентралізаційних реформ [11].

$\mathrm{Ta}$, незважаючи на довгий термін упровадження, ця реформа в Латвії вирішила широке коло нагальних проблем та створила підгрунтя для розвитку місцевого самоврядування у вирішенні актуальних питань та посилила вплив на місцевий економічний розвиток [12].

Особливості введення в дію децентралізації у різних країнах дає змогу зрозуміти, що досвід кожної є досить індивідуальним для кожної з них.

У результаті проведеного аналізу варто підкреслити основні напрями для проведення реформ із децентралізації в Україні:

- розділення повноважень, прав та обов'язків залежно від рівня влади, що дасть змогу урівноважити інтереси у системі публічних відносин;

- створення та впровадження ефективної регіональної політики, спрямованої на забезпечення рівносильного місцевого та регіонального розвитку;

- здійснення адміністративно-територіального поділу без загрози для цілісності держави та іiі суверенітету;

- стимулювання збільшення прав територіальних громад щодо вирішення проблем їх особистого забезпечення;

- здійснення бюджетної реформи $з$ урахуванням інтересів як на рівні держави, так і на рівні місцевих одиниць.

Висновки. Кожна досліджувана країна проходила низку перетворень на шляху до того розвиненого стану, в якому вони $є$ сьогодні. Процес децентралізації в кожній був дуже громіздким та довготривалим та не закінчений до кінця в жодній державі. Від історії становлення держав, соціальних та територіальних характеристик, а також ментальності їхніх громадян залежить те, наскільки довгим та складним буде процес реформування. Не можна стверджувати, що в якійсь із вибраних країн адміністративні перетворення були неуспіш- 
ними. Але на прикладі Польщі можемо бачити, що їхня система управління натепер є більш ефективною та досконалою, ніж в Італії чи тій самій Литві. Адже завдяки краще сформованим умовам реформ та відповідним законам у Польщі не виникало проблем із розподілом коштів та фінансовим навантаженням на окремі ланки системи. Україні варто взяти це до уваги, адже вже нині є труднощі iз процесом децентралізації в нашій країні.

Вважаємо, що використання «під кальку» досвіду європейських держав в Україні - це неправильно. Кожна держава має притаманні ій особливості: історію, економіку, культуру, ресурсний потенціал. Тому реформа децентралізації в Україні є однією з базових реформ, що має на меті змінити наявну адміністративну систему та інтегрувати Україну в Свропейську хартію місцевого самоврядування.

Отже, результатом децентралізації повинно бути будівництво розвиненої, сильної та демократичної держави, яка не буде розпорошувати свої ресурси, а дасть можливість місцевим органам влади вирішувати та спрямовувати ресурси для вирішення своїх проблем.

\section{Список використаних джерел:}

1. Бориславська О., Заверуха І., Школик А. Децентралізація публічної влади: досвід європейських країн та перспективи України. Центр політико-правових реформ. Київ: Москаленко О.М., 2012. 212 с.

2. Іжа М. Показник децентралізаційних процесів у країнах Європи. Вісник СевНТУ. 2010. Вип. 112. веб. сайт URL: http://sevntu.com.ua/jspui/bitstream/123456789/3288/1/112-30.pdf. (дата звернення: 6.05.2020).

3. Хріпливець Д.Є. Теоретичні засади моделей місцевого самоврядування. веб. сайт URL: http://www.dy.nayka.com.ua/ ?op $=1 \& \mathrm{z}=188 \% 20$. (дата звернення: 6.05.2020).

4. Камінська Н. Децентралізація і досвідії проведення у зарубіжних країнах. веб. сайт URL: http://www. irbis-nbuv.gov.ua/ .../cgiirbis_64.exe?. ( дата звернення: 6.05.2020).

5. Децентралізація: від добровільності до примусовості. веб. сайт URL:https://rada.oporaua.org/analityka/ a-iak-u-nykh/8585 detsentralizatsiia-vid-dobrovilnosti-do-prymusovosti (дата звернення: 6.05.2020).

6. Закон щодо функціонування міст метрополій, провінцій, об'єднання та розділення комун. веб. сайт URL: https://www.normattiva.it/uri-res/N2Ls?urn:nir:stato:legge:2014;56 (дата звернення: 6.05.2020).

7. Децентралізація влади на основі кращих іноземних практик та українських законодавчих ініціатив. веб. сайт URL: http://www.uiip.org.ua/wpcontent/uploads/2015/05/\%D1\%80\%D0\%BE\%D0\%B1\%D0\%BE\%D1\%87\%D1\%96\%D0\% BC\%D0\%B0\%D1\%82\%D0\%B5\%D1\%80\%D1\%96\%D0\%B0\%D0\%BB\%D0\%B8\%D0\%B4\%D0\%BB $\%$ D1\%8F\%D1\%83\% D1\%87\%D0\%B0\%D1\%81\%D0\%BD\%D0\%B8\%D0\%BA\%D1\%96\%D0\%B2\%D0\%B7\%D0\%B0\%D1\%85\%D0\%BE\%D0\% B4\%D1\%96\%D0\%B2.pdf (дата звернення: 6.05.2020).

8. Децентралізація: досвід Польщі та втілення реформи в Україні. веб. сайт URL: https://www.radiosvoboda. org/a/28742629.html (дата звернення: 6.05.2020).

9. Розвиток процесу децентралізації в Румунії. веб. сайт URL: http://pgp-journal.kiev.ua/archive/2018/6/40.pdf (дата звернення: 6.05.2020).

10. Децентралізація публічної влади. веб. сайт URL: https://www.pravo.org.ua/files/ebook/Decentral_Power_web.pdf (дата звернення: 6.05.2020).

11. Децентралізація: досвід європейських країн. веб. сайт URL:https://ukr.lb.ua/blog/yuriy_odarchenko/399704_ detsentralizatsiya_dosvid.html (дата звернення: 6.05.2020).

12. Як провели реформу адміністративно-територіального устрою та місцевого самоврядування у Латвії. веб. сайт URL: http://www.csi.org.ua/?p=4802 (дата звернення: 6.05.2020).

\section{References:}

1. Boryslavska O.M., Zaverukha I.B., Shkolyk A.M. (2012) Detsentralizatsiia publichnoi vlady: dosvid yevro-peiskykh krain ta perspektyvy Ukrainy [Decentralization of public authority: experience of European countries and prospects of Ukraine]. Kyiv.

2. Izha M. (2010) Pokaznyk detsentralizatsiinykh protsesiv u krainakh Yevropy. Visnyk SevNTU. Vyp. 112. Available at: URL: http://sevntu.com.ua/jspui/bitstream/123456789/3288/1/112-30.pdf. (accessed 06 May 2020).

3. Khriplyvets D.Ye. (2010). Teoretychni zasady modelei mistsevoho samovriaduvannia.[ Theoretical principles of local government models]. Available at: URL:http://www.dy.nayka.com.ua/?op=1\&z=188\%20. (accessed 06 May 2020)

4. Kaminska N. (2014) Detsentralizatsiia i dosvid yii provedennia u zarubizhnykh krainakh. [ Decentralization and the experience of its implementation in foreign countries.] website Available at: URL: http://www. irbis-nbuv.gov.ua/.../cgiirbis_64. exe? (accessed 06 May 2020)

5. Detsentralizatsiia: vid dobrovilnosti do prymusovosti [Decentralization: from voluntariness to coercion]. website Available at: URL: https://rada.oporaua.org/analityka/a-iak-u-nykh/8585 detsentralizatsiia-vid-dobrovilnosti-do-prymusovosti (accessed 06 May 2020).

6. Zakon shchodo funktsionuvannia mist metropolii, provintsii, obiednannia ta rozdilennia komun. [Law on the functioning of cities, metropolises, provinces, associations and divisions of communes]. website Available at: URL: https://www.normattiva.it/uri-res/N2Ls?urn:nir:stato:legge:2014;56 (accessed 06 May 2020).

7. Detsentralizatsiia vlady na osnovi krashchykh inozemnykh praktyk ta ukrainskykh zakonodavchykh initsiatyv. [ Decentralization of power on the basis of best foreign practices and Ukrainian legislative initiatives.] website Available at: URL: http://www.uiip.org.ua/wpcontent/uploads/2015/05/\%D1\%80\%D0\%BE\%D0\%B1\%D0\%BE\%D1\%87\%D1\%96\%D0\% BC\%D0\%B0\%D1\%82\%D0\%B5\%D1\%80\%D1\%96\%D0\%B0\%D0\%BB\%D0\%B8\%D0\%B4\%D0\%BB\%D1\%8F\%D1\%83\% D1\%87\%D0\%B0\%D1\%81\%D0\%BD\%D0\%B8\%D0\%BA\%D1\%96\%D0\%B2\%D0\%B7\%D0\%B0\%D1\%85\%D0\%BE\%D0\%B4\%D1\%96\%D0\%B2.pdf (accessed 06 May 2020). 
8. Detsentralizatsiia: dosvid Polshchi ta vtilennia reformy v Ukraini.[ Decentralization: the experience of Poland and the implementation of reform in Ukraine]. website Available at: URL: https:/www.radiosvoboda.org/a/28742629.html (accessed 06 May 2020).

9. Rozvytok protsesu detsentralizatsii $v$ Rumunii. [Development of the decentralization process in Romania]. website Available at: URL: http://pgp-journal.kiev.ua/archive/2018/6/40.pdf (accessed 06 May 2020).

10. Detsentralizatsiia publichnoi vlady. [Decentralization of public power]. website Available at: URL: https://www.pravo.org.ua/files/ebook/Decentral_Power_web.pdf (accessed 06 May 2020).

11. Detsentralizatsiia: dosvid yevropeiskykh krain. [Decentralization: the experience of European countries]. website Available at: URL: https://ukr.lb.ua/blog/yuriy_odarchenko/399704_detsentralizatsiya_dosvid.html (accessed 06 May 2020).

12. Yak provely reformu administratyvno-terytorialnoho ustroiu ta mistsevoho samovriaduvannia $u$ Latvii. [How was the reform of the administrative-territorial system and local self-government in Latvia.] website Available at: URL: http://www.csi.org.ua/?p=4802 (accessed 06 May 2020).

\section{Lyvdar Marta, Fedevych Liudmyla, Kornachuk Olesia} Lviv Polytechnic National University

\section{EXPERIENCE OF THE DECENTRALIZATION PROCESS IN THE EUROPEAN COUNTRIES}

Decentralization is primarily a reorganization of state power, which takes place in the transfer of significant powers and resources from state bodies to local self-government bodies. The main goal of decentralization remains to ensure the balance of powers and responsibilities with the necessary resources to meet the needs of citizens. Financial decentralization aims to expand the rights and capabilities of local governments to use funds, forecast and approve regional budgets.

Peculiarities and mechanisms of decentralization in the European countries and coverage of their main achievements and problems in the reform processes are studied. The main aspects of the division of powers in the European countries are highlighted.

The experience of foreign countries is considered, which shows ways to accumulate funds in local budgets and improve the quality of life of citizens, as well as to evenly burden the regions according to their capabilities. Particular attention should be paid to the experience of decentralization in the countries that were part of the Soviet Union. The relevance of this lies in the similarity of conditions in these countries and the Ukrainian ones. That is, it can be a good example for Ukraine to avoid certain mistakes.

Peculiarities and mechanisms of decentralization in the European countries, in particular, the experience of Italy, Poland, Romania and Latvia, are studied.

Features of the introduction of decentralization in different countries makes it clear that the experience of each of them is quite individual. Each country under study has undergone a number of transformations on the way to the developed state in which it is today. The experience of Poland is the most interesting for Ukraine. Budget decentralization in Poland has been the final reform after changes in local self-government and administrative-territorial organization.

The main directions for bringing decentralization reforms in Ukraine are highlighted.

The most important thing is budget decentralization, which should reduce the role of the state in financing the development of communities and regions while creating opportunities to strengthen the autonomy of local budgets.

The result of the reform should be the building of a developed, strong and democratic state that will not scatter its resources, this will allow local authorities to decide and direct resources to solve their problems.

Key words: decentralization, budget, local government, region.

JEL classification: F01, O40, R58. 